\title{
A NEW SPECIES OF THE FAMILY Theaceae FROM CENTRAL VIETNAM
}

\author{
Luu Hong Truong ${ }^{1 *}$, Tran Gioi ${ }^{2}$, Nguyen Quoc Dat ${ }^{1}$, Nguyen Hieu Cuong ${ }^{1}$ \\ ${ }^{1}$ Southern Institute of Ecology, VAST \\ ${ }^{2}$ Khanh Hoa Association for Conservation of Nature and Environment
}

\begin{abstract}
Camellia honbaensis (sp. n.) is described as a new species of section Piquetia from Hon Ba Nature Reserve, Khanh Hoa province, Central Vietnam. The new taxon is close to $C$. piquetiana, but differs from the later by having ovate, slightly longitudinally striated and 3-4locular ovaries and 3-4 styles connate at basal 1/5-1/3 part and glabrous on apical 1/4 part. A key to all known species of the section is given.
\end{abstract}

Keywords: Theaceae, Camellia, Piquetia, new species, Vietnam.

Citation: Luu Hong Truong, Tran Gioi, Nguyen Quoc Dat, Nguyen Hieu Cuong, 2018. A new species of the family Theaceae from central Vietnam. Academia Journal of Biology, 40(4): 23-28. https://doi.org/10.15625/2615-9023/v40n4.12919.

*Corresponding author email: hongtruongluu@gmail.com

Received 31 Juy 2018, accepted 20 December 2018

\section{INTRODUCTION}

Camellia $\mathrm{L}$. is one of the largest genus of the Theaceae compring 120 to 300 species. One of its sections, Piquetia (Pierre) Sealy, is endemic to Vietnam and characterised by the following characters: large leaves $(\geq 29 \mathrm{~cm} \times$ $\geq 9.5 \mathrm{~cm}),(1) 3-5$ nodding and pedicellate flowers on short ( $8 \mathrm{~mm}$ long) shoots in the axils of the leaves; very stout and upwards thickened pedicel; 2-3 persistent bracteoles; $3-5$ persistent sepals; $\geq 5$ petals; stamens free above the union with the petals and puberulous inside; densely hairy gynoecium; 3-6 free styles (Chang, 1981; Chang \& Bartholomew, 1984; Ming, 2000; Ming \& Bartholomew, 2007; Orel \& Curry, 2015; Richards et al., 2002 \& 2003; Sealy, 1958). Prior to this paper, there have been five species described for this section, namely $C$. dalatensis Luong, Tran \& Hakoda, $C$. dongnaiensis Orel, $C$. longii Orel \& Luu, $C$. piquetiana (Pierre) Sealy and $C$. sonthaiensis Luu, Luong, Q. D. Nguyen \& T. Q. T. Nguyen (Luong et al., 2015; Orel, 2006; Orel et al., 2016; Pham-hoang, 1991 \& 2000;
Pierre, 2887; Pitard, 1910; Sealy, 1958; Tran, 2002; Tran \& Luong, 2012). In August 2012, the authors of this paper encountered a Camellia species with large leaves and very young fruits in Hon Ba Nature Reserve, Khanh Hoa province. Our subsequent visits to the reserve from 2013 to 2015 collected additional flowering and fruiting specimens. Our careful examination of its morphological characteristics indicated that the species belongs to Camellia sect. Piquetia but differs from all other known species in the section, and thus it is proposed here as a new species.

\section{MATERIALS AND METHODS}

The studied material was collected from Hon Ba Nature Reserve, Khanh Hoa province. The new species was determined based on comparison of its morphological characteristics with its close congeners'.

\section{RESULTS AND DISCUSSION}

Key to all alredy known species of Camellia sect. Piquetia (based on [3, 7, 9, 10-16, 18]) 


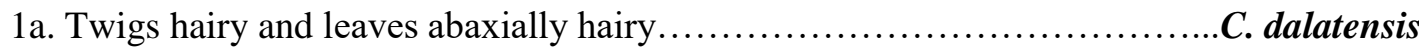

1b. Twigs and leaves glabrous........................................................

2a. Petals yellow to graduated yellow apricot to intensely pink ...........................

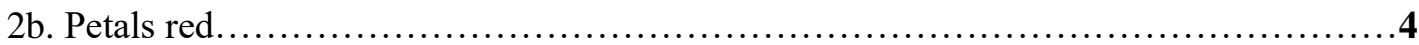

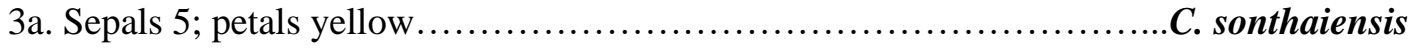

3b. Sepals 3; petals graduated yellow apricot to intensely pink.............C. dongnaiensis

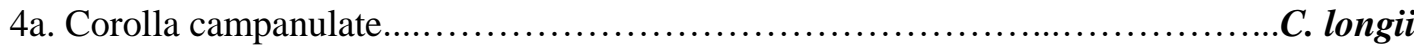

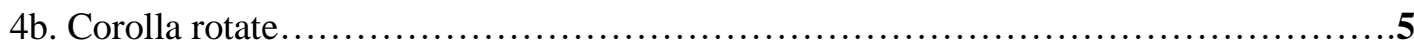

5a. Ovary discoid, 5-6-lobulate, 5-6-locular; styles 5-6.................... piquetiana

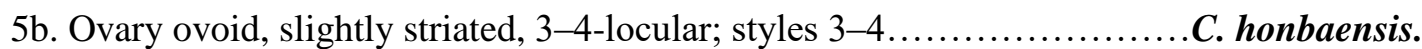

\section{Description of the new species}

C. honbaensis Luu, Q. D. Nguyen \& G. Tran, sp. n.

Allied to $C$. piquetiana in general appearance but different in having ovate, slightly longitudinally striated and 3-4-locular ovaries and 3-4 styles connate at basal $1 / 5-1 / 3$ part and glabrous on apical $1 / 4$ part (vs. discoid, 5-6-lobulate and 5-6-locular ovaries and 5-6 free and fully hairy styles).

Shrub 2 to $4 \mathrm{~m}$ high, evergreen, with arching stem, sparsely branched, branches slender; young branches green, glabrous, shiny; mature branches light brown. Leaves pendulous, glabrous, narrowly lanceolate to oblong-elliptic, obtuse at base, acuminate at apex, with shallowly toothed margin, coriaceous, adaxially light green, abaxially pale green, $26-43 \mathrm{~cm}$ long, $4.5-10.6 \mathrm{~cm}$ wide; midrib adaxially and abaxially prominent; secondary venation slightly brochidodromous, with 17-26 pairs of arched veins, adaxially slightly raised, abaxially prominent; tertiary venation adaxially and abaxially distinct; leaf petioles purple to light green and falcate when mature, partially obstructed by leaf lamina on adaxial side, glabrous, $2-2.2 \mathrm{~cm}$ long, 2.5-3.0 $\mathrm{mm}$ wide, thick. Flowers pedunculate, 1-3, pendulous, borne on a bracteate $0.4-0.6 \mathrm{~mm}$ long shoot in the axils; bracts (sensu Sealy 1958) 2-6, with 1-3 subtending the flowers, the others barren, unguiform, persistent; pedicels very stout, thickened upwards, slightly decurved, 25-29 mm long, $3 \mathrm{~mm}$ wide at the proximal end, $7 \mathrm{~mm}$ wide at distal end, shiny or crackled and corky, glabrous, bearing 2 or 3 bracteoles; bracteoles triangular, 2-2.5 mm long, 2-2.5 mm wide at base, abaxially pubescent, adaxially glabrous, appressed to and scattered along the pedicel, persistent; open flowers evenly circular, ca. $4-4.5 \mathrm{~cm}$ in diameter; sepals 5 , yellowish green, 6-7 $\mathrm{mm}$ long, 7-9 mm wide, persistent, broadly ovate to suborbicular, concave, coriaceous, finely hairy on outer surface, with ciliate margin; petals $7-8$, finely hairy on outer surface, ciliate at apex, red to purplish red, with white margin, 1.2-2.6 cm long, $1-2.8 \mathrm{~cm}$ wide, orbicular to obovate, concave, with margin becoming revolute, stamens around 300 and slightly shorter than styles, filaments $1.8-2.1 \mathrm{~cm}$ long, white to lightly yellow, arranged in 7-8 whorls, outer filaments glabrous, basally united to the petals for $3-5 \mathrm{~mm}$, free above the union, inner filaments hairy on basal $2 / 5$ part, glabrous above, basally united to each other for 4-10 $\mathrm{mm}$; anthers yellow, $1.2 \mathrm{~mm}$ long, $0.7 \mathrm{~mm}$ wide, basifixed; ovary superior, ovoid, with slight longitudinal striations, yellow, white hairy, 3-4-locular, ca. 3-4 mm long, 3-4 mm in diameter, with 2 ovules per locule; styles 3-4, connate at basal 1/5-1/3 part, free above, yellowish, hairy on basal $3 / 4$ part, glabrous on apical $1 / 4$ part, $1.7-2.1 \mathrm{~mm}$ long, $1 \mathrm{~mm}$ wide 
at base, $0.2 \mathrm{~mm}$ wide at apex, stigma flat. Mature fruits flattened-globose, 3-4 lobed, hairy, $4.5-5.0 \mathrm{~cm}$ in diameter, $2.5-3 \mathrm{~cm}$ high, with persistent sepals, dehiscing distally into 3-4 parts; columella stout, $0.8-1.2 \mathrm{~cm}$ long, 6-8 $\mathrm{mm}$ wide; seeds 2 per locule, piano-convex, about $1.7-1.8 \mathrm{~cm}$ long and $1.3-1.4 \mathrm{~cm}$ wide (Fig. 1).
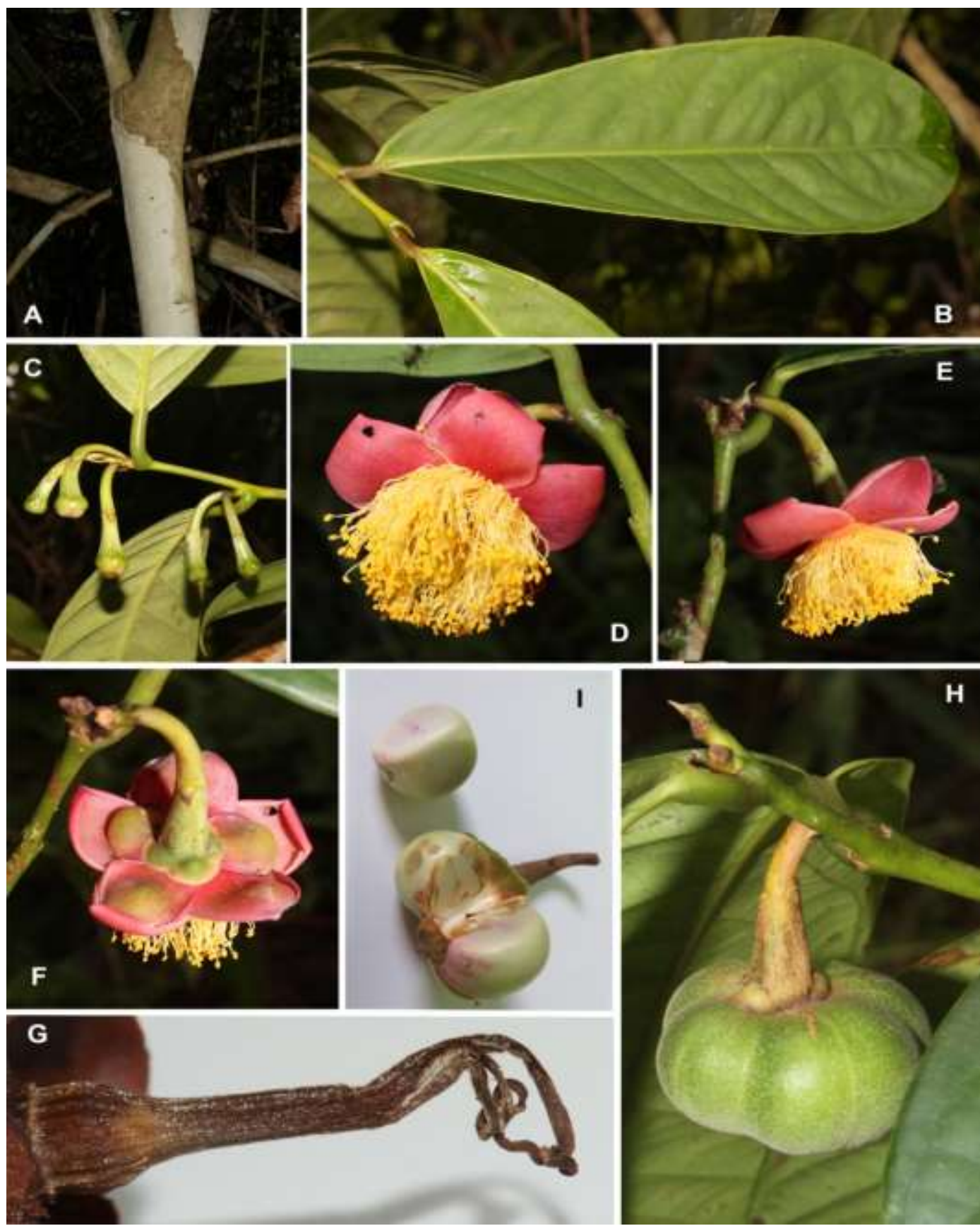

Figure 1. Camellia honbaensis. sp. n., A. Trunk. B. Young shoot and leaf. C. Flower buds with bracts and bracteoles. D. Open flower. E. Side view of flower. F. Arrangement of sepals and petals. G. Gynoecium. H: Nearly mature fruit. I: Nearly mature seeds 
Typus: VIETNAM. Central Vietnam, Khanh Hoa province: Hon Ba Nature Reserve, approximate coordinates $12^{\circ} 06^{\prime} 41^{\prime \prime} \mathrm{N}$ and 108 58'51" E, $650 \mathrm{~m}$ elevation, 22 January 2015, Luu Hong Truong and Tran Gioi Luu 1101 (holotype SGN!, isotypes SGN!, VNMN!); 8 April 2013, Luu Hong Truong and Tran Gioi KH1140 (paratype SGN!), 24 March 2014, Luu Hong Truong and Tran Gioi KH1140b (paratype SGN!).

\section{Etymology}

The species is named after the type location, Hon Ba Mountain.

\section{Proposed Vietnamese name}

Tra Yy Hon Ba.

\section{Ecology}

C. honbaensis, sp. n. was found in understorey of lowland tropical evergreen closed forests at around $650 \mathrm{~m}$ above the sea level. Flowering was seen in January and fruiting in April.

\section{Notes}

The new species appears to be very similar to many taxa of Camellia, especially to $C$. piquetiana, the type of the section, in most of the typical characteristics of habit, leaf size, flowers and fruits. However, $C$. piquetiana can be distinguished by its discoid and 5-6-locular ovaries and 5-6 free and fully hairy styles (Pham-hoang, 1991; Pierre, 1887; Pitard, 1910; Sealy, 1958). In the section, $C$. longii also has red petals and glabrous large leaves but it differs from the new species in its campanulate flowers, red sepals and peduncle, 4-6-carpellate discoid and lobulate ovaries and 4-6 apically glabrous styles proximally fused for ca. $5.0 \mathrm{~mm}$ (Orel et al., 2014). Besides, $C$. dongnaiensis is distinguishable from $C$. honbaensis in having 3 sepals and graduated yellow apricot to intensely pink petals (Orel, 2016). The new species is distinct from all the rest species of the section as they have yellow flowers (Table 1).

Table 1. Key morphological differences among Camellia sect. Piquetia species

\begin{tabular}{|c|c|c|c|c|c|c|}
\hline Characteristics & Leaves & Flowers & Sepals & Stamens & Ovary & Styles \\
\hline C. dongnaiensis & glabrous & $\begin{array}{c}\text { campanulate, } \\
\text { graduated yellow } \\
\text { apricot to } \\
\text { intensely pink petals }\end{array}$ & 3 & $300-500$ & ovoid, striated & $\begin{array}{c}5-6, \text { free, } \\
\text { glabrous }\end{array}$ \\
\hline C. longii & glabrous & campanulate, red & 5 & $250-300$ & $\begin{array}{c}\text { almost diamond } \\
\text { shaped, slightly } \\
\text { striated }\end{array}$ & $\begin{array}{l}\text { 4-6, proximally } \\
\text { finely pubescent, } \\
\text { distally glabrous }\end{array}$ \\
\hline C. piquetiana & glabrous & rotate, red & 5 & $?$ & $\begin{array}{l}\text { discoid, 5-6- } \\
\text { lobed }\end{array}$ & $\begin{array}{c}5-6, \text { free, fully } \\
\text { hairy }\end{array}$ \\
\hline C. sonthaiensis & glabrous & rotate, yellow & 5 & $\sim 260$ & $\begin{array}{c}\text { ovoid, slightly } \\
\text { striated, 3-4- } \\
\text { lobed } \\
\end{array}$ & $\begin{array}{c}3-4, \text { free, } \\
\text { basally densely } \\
\text { hairy } \\
\end{array}$ \\
\hline C. honbaensis & glabrous & rotate, red & 5 & $\sim 300$ & $\begin{array}{l}\text { ovoid, slightly } \\
\text { striated, 3-4- } \\
\text { lobed }\end{array}$ & $\begin{array}{c}\text { 3-4, connate at } \\
\text { basal } 1 / 5-1 / 3 \\
\text { part, basally } \\
\text { densely hairy, } \\
\text { glabrous on } \\
\text { apical } 1 / 4 \text { part }\end{array}$ \\
\hline C. dalatensis & $\begin{array}{c}\text { abaxially } \\
\text { hairy }\end{array}$ & rotate, yellow & 5 & $>300$ & $\begin{array}{c}\text { ovoid, slightly } \\
\text { striated, 4-5- } \\
\text { lobed } \\
\end{array}$ & $\begin{array}{c}4-5 \text {, free, fully } \\
\text { hairy }\end{array}$ \\
\hline
\end{tabular}


The red flowers and very large glabrous leaves of $C$. honbaensis also recalls those of several species assigned to other Camellia sections, namely $C$. campanulata Orel, Curry \& Luu (sect. Lecomtia Orel), C. cattienensis Orel (sect. Archecamellia Sealy), C. hongiaoensis Orel \& Curry (sect. Dalatia Orel) and C. krempfii (Gagnep.) Sealy (sect. Archecamellia Sealy) and but all these species, like $C$. longii and $C$. dongnaiensis, have campanulate and much larger flowers which make them readily different from the new taxon (Gagnepain, 1941; Orel \& Curry, 2014; Orel \& Curry, 2015; Orel \& Wilson, 2012; Pham-hoang, 1991; Pierre, 1887; Pitard, 1910; Sealy, 1958). In fact, C. campanulata, C. cattienensis, $C$. dongnaiensis and $C$. longii do look alike and so do $C$. hongiaoensis and C. krempfii; however, these possible synonymities will be the subject for another paper.

The size of leaves and the structure of flowers in $C$. honbaensis are similar to those in $C$. decora Orel, Curry \& Luu and $C$. tadungensis Orel, Curry \& Luu (both of sect. Dalatia) but the two latter are different in having yellow to orange and pink flowers (Orel \& Curry, 2015). In addition, C. decora has dark green and shiny leaves with round to cordate bases, around 200 basally pink and apically white filaments and reddish orange petals while $C$. tadungensis does apically pale light yellow and basally red petals, 5-6 styles with hairs on basal $1 / 2$ part, basally red to purple and apically yellow filaments, and around 20-lobed fruits.

Acknowledgements: This work is a result mainly from two contracts numbered $10 / \mathrm{HĐ}$ CCBVMT and 13/HĐ-STNMT signed between Khanh Hoa provincial Department of Natural Resource and Environment and Southern Institute of Ecology. The field work was partially supported by Vietnam National Foundation for Science and Technology Development (NAFOSTED) under grant number 106-NN.03-2013.65. The authors are grateful to the directors and staffs of Hon Ba Nature Reserve, especially Mr. Nguyen Hanh and $\mathrm{Mr}$. Le Kim Hoan $\mathrm{Vu}$, for their permits and support for the field work. The authors thank the anonymous reviewer for his constructive critical comments that helped improve the manuscript.

\section{REFERENCES}

Chang H. T., 1981. A taxonomy of the genus Camellia. Acta Scientiarum Naturalium Universitatis Sunyatseni, Monograph Series, 1: 1-180.

Chang H. T., Bartholomew B., 1984. Camellias. Portland, OR. Timber Press.

Gagnepain F., 1941. Ternstroemiacees Nouvelles d'Indochine. Notulae Systematicae, 10: 112-131.

Luong V. D., Luu H. T., Nguyen T. Q. T., Nguyen Q. D., 2015. Camellia sonthaiensis (Theaceae), a new species from Vietnam. Annales Botanici Fennici, 52: 289-295.

Ming T. L., 2000. Monograph of the Genus Camellia. Kunming, China: Yunnan Science and Technology Press.

Ming T. L., Bartholomew B., 2007. Theaceae. In: Wu ZY, Raven PH \& Hong DY (eds) Flora of China, Vol. 12. Science Press, Missouri Botanical Garden Press.

Orel G., 2006. A new species of Camellia section Piquetia (Theaceae) from Vietnam. Novon, 16: 244-47.

https://doi.org/10.3417/1055-3177(2006)16 [244:ANSOCS]2.0.CO;2

Orel G., Curry A. S., 2014. A new species of Camellia Section Dalatia (Theaceae) from Vietnam. Telopea, 17: 99-105.

https://doi.org/10.7751/telopea20147551

Orel G., Curry A. S., 2015. In Pursuit of Hidden Camellias: 32 new Camellia species from Vietnam and China. Theaceae Exploration Associates: Sydney. 
Orel G., Wilson P. G., 2012. Camellia cattienensis: a new species of Camellia (sect. Archaecamellia: Theaceae) from Vietnam. Kew Bulletin, 66: 565-569.

https://doi.org/10.1007/s12225-012-9317-0.

Orel G., Wilson P., Luu H. T., 2014. Camellia curryana and $C$. longii spp. nov. (Theaceae) from Vietnam. Nordic Journal of Botany, 32: 42-50. https://doi.org/10.1111/j.17561051.2013.00399.x

Pham-Hoang H., 1991. Theaceae. An Illustrated Flora of Vietnam, Tome I, 1: 511-539. Mekong Printing. Montréal. (In Vietnamese).

Pham-Hoang H., 2000. Theaceae. An Illustrated Flora of Vietnam, 1: 412-434. Youth Publishing House, Ho Chi Minh City. (In Vietnamese).

Pierre L., 1887. Flore Forestière de Cochinchine, 2: 119. Paris.

Pitard C. J., 1910. Ternstroemiacées. In: Lecomte $\mathrm{MH}$ (ed) Flore Générale de
l'Indo-Chine, tome 1, fasc. 4. Paris: Masson et Cie.

Richards G., Orel G., Harland C., Jones S., 2002. The elusive Camellia piquetiana. International Dendrology Society Yearbook, 137-141.

Richards G. D., Orel G., Harland C., Jones S. 2003. The rediscovery of Camellia piquetiana, a short communication. International Camellia Journal, 35: $54-56$.

Sealy J. R., 1958. A revision of the genus Camellia. Royal Horticultural Society, London.

Tran N., 2002. Biodiversity of the genus Camellia of Vietnam. International Camellia Journal, 34: 80-85.

Tran N., Luong V. D., 2012. Camellia dalatensis: a new species and precious gene should be conserved. VNU Journal of Science, Natural Sciences and Technology, 28(2S): 34-36. 